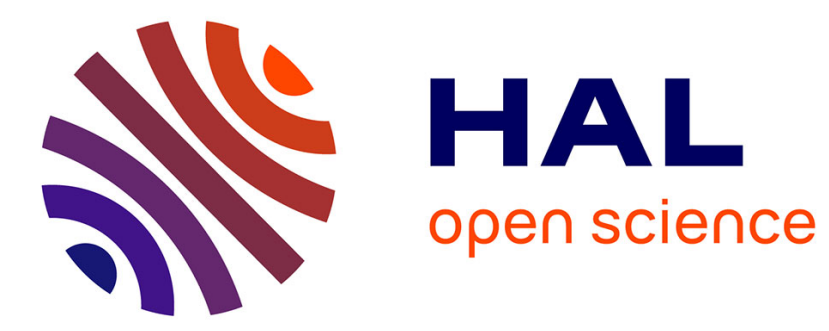

\title{
Influence of $\mathrm{NaX}(\mathrm{X}=\mathrm{I}$ or $\mathrm{Cl})$ additions on GeS2-Ga2S3 based glasses
}

\author{
Antoine Brehault, Solenn Cozic, Rémi Boidin, Laurent Calvez, Eugène \\ Bychkov, Pascal Masselin, Xianghua Zhang, David Le Coq
}

\section{To cite this version:}

Antoine Brehault, Solenn Cozic, Rémi Boidin, Laurent Calvez, Eugène Bychkov, et al.. Influence of $\mathrm{NaX}(\mathrm{X}=\mathrm{I}$ or $\mathrm{Cl}$ ) additions on GeS2-Ga2S3 based glasses. Journal of Solid State Chemistry, 2014, 220, pp.238-244. 10.1016/j.jssc.2014.09.005 . hal-01069227

\section{HAL Id: hal-01069227 \\ https://hal.science/hal-01069227}

Submitted on 9 Dec 2014

HAL is a multi-disciplinary open access archive for the deposit and dissemination of scientific research documents, whether they are published or not. The documents may come from teaching and research institutions in France or abroad, or from public or private research centers.
L'archive ouverte pluridisciplinaire HAL, est destinée au dépôt et à la diffusion de documents scientifiques de niveau recherche, publiés ou non, émanant des établissements d'enseignement et de recherche français ou étrangers, des laboratoires publics ou privés. 


\title{
Influence of $\mathrm{NaX}(X=\mathrm{I}$ or $\mathrm{Cl})$ additions on $\mathrm{GeS}_{2}-\mathrm{Ga}_{2} \mathrm{~S}_{3}$ based glasses
}

\author{
A. Bréhault ${ }^{\mathrm{a}}$, S. Cozic ${ }^{\mathrm{a}}$, R. Boidin ${ }^{\mathrm{b}}$, L. Calvez $^{\mathrm{a}}$, E. Bychkov ${ }^{\mathrm{b}}$, P. Masselin ${ }^{\mathrm{b}}$, X. Zhang ${ }^{\mathrm{a}}$, \\ D. Le Coq ${ }^{\mathrm{a}, *}$
}

a Institut des Sciences Chimiques de Rennes, Eq. Verres et Céramiques, UMR 6226 CNRS, Université de Rennes 1, 35042 Rennes Cedex, France

${ }^{\mathrm{b}}$ Laboratoire de Physico Chimie de l'Atmosphère, EA 4493, Université du Littoral Côte d'Opale, 59140 Dunkerque, France

\section{A R T I C L E I N F O}

\section{Article history:}

Received 17 April 2014

Received in revised form

2 September 2014

Accepted 6 September 2014

Available online 16 September 2014

\section{Keywords:}

Chalcogenide glasses

Optical properties

Electrical conductivity

\begin{abstract}
A B S T R A C T
Chalcogenide glasses in the pseudo-ternary system $\mathrm{NaX}-\mathrm{GeS}_{2}-\mathrm{Ga}_{2} \mathrm{~S}_{3}(X=\mathrm{Cl}$ or I ) were synthesized. Different series were investigated in order to highlight the influence of the sodium halide addition on two different host glasses $\left(\mathrm{GeS}_{2}\right)_{80}\left(\mathrm{Ga}_{2} \mathrm{~S}_{3}\right)_{20}$ and $\left(\mathrm{GeS}_{2}\right)_{72}\left(\mathrm{Ga}_{2} \mathrm{~S}_{3}\right)_{28}$. Macroscopic properties including density and characteristic temperatures, such as glass transition temperatures $T_{g}$ and crystallization temperature $T_{x}$, were determined for a maximum molar content of $\mathrm{NaX}$ equal to $15 \%$. The evolution of the optical band-gap and the chemical stability following the composition were also studied. Conductivity measurements were also performed and compared to other Li-based $\mathrm{GeS}_{2}-\mathrm{Ga}_{2} \mathrm{~S}_{3}$ glasses . The results were discussed taking into account the cation and anion nature and also the glass packing density.
\end{abstract}

(c) 2014 Elsevier Inc. All rights reserved.

\section{Introduction}

Chalcogenide glasses based on the $\mathrm{GeS}_{2}-\mathrm{Ga}_{2} \mathrm{~S}_{3}$ system are very attractive materials since they have low phonon energy, high refractive index and wide transmission range making them very good candidates in various fields. The structure of these pseudobinary glasses has been widely investigated and literature proposes corner- and edge-shared $\mathrm{Ge}(\mathrm{Ga}) \mathrm{S}_{4}$ tetrahedra, ethane-like $\mathrm{S}_{3} \mathrm{Ga}-\mathrm{GaS}_{3}$ units connected by bridging sulfur, and more recently $\left[\mathrm{Ge}(\mathrm{Ga}) \mathrm{S}_{1 / 3} \mathrm{~S}_{3 / p}\right]_{3}, \quad(p=2,3)$ triclusters [1-3]. Even this pseudobinary system is already interesting thanks to its intrinsic properties, it is more pleasing because of the large possibility to be doped for optical or conductivity applications. For example, they possess a high solubility of rare-earth ions and consequently they are very promising as host glass matrix in the fluorescence material domain in the near- and mid-infrared regions [4-7]. Also, the possibility to add alkali halide in this system to extend the visible and infrared transparency range and to affect crystallization behavior by self-nucleating and nucleating agent was also used to promote phase separation and bulk nucleation [8,9]. Subsequently, reproducible infrared transmitting glass-ceramics with enhanced thermo-mechanical properties were produced $[10,11]$. The addition of alkali halide $(M X)$ in germanium gallium sulfide glasses is also very suitable to obtain drastic increase of their ionic conductivity [12]. Indeed, chalcogenide glasses have better

\footnotetext{
* Corresponding author. Tel.: +33 2232354 23; fax: +33223235611.

E-mail address: david.lecoq@univ-rennes1.fr (D. Le Coq).
}

potential than the oxide glasses for solid electrolyte applications $[13,14]$. Moreover, it has also been proved that partial crystallization can be profitable to enhance the ionic conductivity of the oxide or chalcogenide glasses $[15,16]$.

Actually, the main reported works on the conductivity of $M X-\mathrm{GeS}_{2}-\mathrm{Ga}_{2} \mathrm{~S}_{3}$ glasses concern $\mathrm{MX}$ with $\mathrm{M}=\mathrm{Li}^{+}$or $\mathrm{Ag}^{+}$and $X=\mathrm{I}^{-}$or $\mathrm{Cl}^{-}[17,18]$. Surprisingly, although the use of sodium salts $(\mathrm{NaX})$ in the composition of chalcogenide glasses could be a good alternative as solid-state electrolyte in battery [19], the study of $\mathrm{NaX}$-doped chalcogenide glass system is relatively poor.

This paper comes within the scope of preliminary study of sodium doped chalcogenide glasses in optic and conductivity fields. The influence of the included salt $\mathrm{NaX}\left(X=\mathrm{I}^{-}\right.$or $\left.\mathrm{Cl}^{-}\right)$in two different host glass matrixes based on $\mathrm{GeS}_{2}$ and $\mathrm{Ga}_{2} \mathrm{~S}_{3}$ is investigated. Thus, the study of two different series for each of the two halogens will also assess the effect of the $\mathrm{GeS}_{2} / \mathrm{Ga}_{2} \mathrm{~S}_{3}$ ratio. Conductivity comparisons with ionic lithium doped $\mathrm{GeS}_{2}-\mathrm{Ga}_{2} \mathrm{~S}_{3}$ glasses are also done.

\section{Experimental}

\subsection{Glass preparation}

Glass sample compositions, $\left(0.8 \mathrm{GeS}_{2}-0.2 \mathrm{Ga}_{2} \mathrm{~S}_{3}\right)_{100-x}(\mathrm{NaX})_{x}$ $(X=\mathrm{Cl}$ or $\mathrm{I})$ and $\left(0.72 \mathrm{GeS}_{2}-0.28 \mathrm{Ga}_{2} \mathrm{~S}_{3}\right)_{100-x}(\mathrm{NaX})_{x}(X=\mathrm{Cl}$ or I) with $0 \leq X \leq 15$, were synthesized from high purity elements ( $\mathrm{Ge}, \mathrm{Ga}$, and $\mathrm{S}$ of $5 \mathrm{~N}$ ) and compounds ( $\mathrm{NaI}$ and $\mathrm{NaCl}$ of $2 \mathrm{~N}$ ). Thereafter, the two host glass series $0.8 \mathrm{GeS}_{2}-0.2 \mathrm{Ga}_{2} \mathrm{~S}_{3}$ and $0.72 \mathrm{GeS}_{2}-0.28 \mathrm{Ga}_{2} \mathrm{~S}_{3}$ 
will further be $80 \mathrm{GeS}_{2}-20 \mathrm{Ga}_{2} \mathrm{~S}_{3}$ and $72 \mathrm{GeS}_{2}-28 \mathrm{Ga}_{2} \mathrm{~S}_{3}$, respectively. These components were weighed in glove box under $\mathrm{Ar}$ atmosphere in stoichiometric proportions and introduced in a silica ampoule. This ampoule was evacuated $\left(10^{-5} \mathrm{~Pa}\right)$, sealed, and placed in a rocking furnace during $12 \mathrm{~h}$ at $850{ }^{\circ} \mathrm{C}$. The quench was operated in water at room temperature. The sample was finally annealed at $T_{g}-30{ }^{\circ} \mathrm{C}$ for $4 \mathrm{~h}$ before being slowly cooled down to room temperature. The rod of $10 \mathrm{~mm}$ diameter was then cut into cylindrical or parallelepiped slices and after the polishing step the sample was approximately $1 \mathrm{~mm}$ thick. An analogous synthesis procedure with higher temperatures was carried out for lithiumbased glasses.

\subsection{Thermal and density analyses}

The characteristic temperatures, glass transition temperature $\left(T_{g}\right)$ and the crystallization temperature $\left(T_{x}\right)$ corresponding to the onset points, of all these samples were determined with a differential scanning calorimeter (DSC Q20 Thermal Analysis). Glass samples were weighed and sealed in a hermetic aluminum pans. The experiments were performed from room temperature up to $550{ }^{\circ} \mathrm{C}$ under nitrogen atmosphere using a heating rate of $10{ }^{\circ} \mathrm{C} \mathrm{min}^{-1}$.

The measurement of sample density $d$ was performed by a Archimedian method using distilled water as immersion fluid. A Mettler Toledo XS64 balance was used. The sample masses vary between $0.5 \mathrm{~g}$ and $1.5 \mathrm{~g}$.

\subsection{Optical measurements}

Optical transmissions of these glasses were measured with a double beam spectrophotometer (Perkin Elmer Lambda 1050) in the visible and near IR ranges. The typical sample thickness was $1.00 \mathrm{~mm}( \pm 0.20 \mathrm{~mm})$. The infrared transmission measurements were performed using a Bruker Vector 22 Spectrometer.

\subsection{Impedance measurements}

Total electrical conductivity of the samples showing a sufficient ionic conduction was measured with a Hewlett Packard 4194A impedance meter from room temperature to $473 \mathrm{~K}$ corresponding to a temperature below $T_{g}$ for all the glass samples. The impedance measurements were carried out in a frequency range lying from $100 \mathrm{~Hz}$ to $15 \mathrm{MHz}$. For the other samples, we used a Hewlett
Packard 4339B high resistance meter with a 100V-applied voltage in order to determine the dc conductivity. The glass samples were prepared as discs of $10 \mathrm{~mm}$ diameter and $1 \mathrm{~mm}$ thickness with two parallel faces. The polished glass discs were then sputter coated with gold on both sides to form blocking electrodes, meaning that the electrochemical cell for conductivity measurements was Aulglass|Au. The temperature dependence on the conductivity was studied over several cycles. Each heating step measurement was followed by a cooling step measurement in order to study a possible hysteresis that was found to be negligible.

\section{Results and discussion}

\subsection{Macroscopic properties}

The characteristic temperatures $T_{g}$ and $T_{x}$ of investigated glass samples are given in Table 1. As shown in Fig. 1a, the decreasing evolution of $T_{g}$ is systematic following the $\mathrm{NaX}$ content, whatever is the host glass. In the case of $\left(80 \mathrm{GeS}_{2}-20 \mathrm{Ga}_{2} \mathrm{~S}_{3}\right)_{100-x}(\mathrm{NaX})_{x}$, $0 \leq x \leq 15, T_{g}$ decreases from $442{ }^{\circ} \mathrm{C}$ down to $370{ }^{\circ} \mathrm{C}$ and $364{ }^{\circ} \mathrm{C}$ for $\mathrm{NaCl}$ and NaI, respectively. For the other host glass, $\left(72 \mathrm{GeS}_{2}-\right.$ $\left.28 \mathrm{Ga}_{2} \mathrm{~S}_{3}\right)_{100-x}(\mathrm{NaX})_{x}, 0 \leq x \leq 15$, the decrease is less pronounced since $T_{g}$ decreases from $428{ }^{\circ} \mathrm{C}$ down to $383{ }^{\circ} \mathrm{C}$ and $382{ }^{\circ} \mathrm{C}$ for $\mathrm{NaCl}$ and NaI, respectively. This behavior is not surprising since other works in $\mathrm{GeS}_{2}-\mathrm{Ga}_{2} \mathrm{~S}_{3}$ based systems have shown a similar trend, notably in the pseudo-ternary $\mathrm{GeS}_{2}-\mathrm{Ga}_{2} \mathrm{~S}_{3}-\mathrm{CsCl}$ or CsI system $[20,21]$. This is traditionally ascribed to the progressive breaking of $\mathrm{Ge}-\mathrm{S}$ or $\mathrm{Ga}-\mathrm{S}$ bonds forming $\mathrm{Ga}(\mathrm{Ge}) \mathrm{S}_{3 / 2} \mathrm{X}^{-}$that leads to a decrease of the connectivity of the glass network. Fig. 1a also displays greater $\mathrm{NaX}$ dependence for the $80 \mathrm{GeS}_{2}-20 \mathrm{Ga}_{2} \mathrm{~S}_{3}$ series in comparison with the $72 \mathrm{GeS}_{2}-28 \mathrm{Ga}_{2} \mathrm{~S}_{3}$ one, meaning that a higher content of $\mathrm{Ga}_{2} \mathrm{~S}_{3}$ in the host glass composition seems important to keep highest $T_{g}$.

The $\Delta T$ parameter, corresponding to the difference between $T_{g}$ and $T_{x}$ is important to evaluate the thermal stability of the glass. Here, whatever the composition, almost all $\Delta T$ becomes higher than $100{ }^{\circ} \mathrm{C}$ meaning that glass samples are stable. Indeed, their evolution as a function of the $\mathrm{NaX}$ content is plotted in Fig. $1 \mathrm{~b}$ and it is noticed that $\Delta T$ increases although $T_{g}$ decreases. The more positive effect of $\mathrm{NaI}$ compared to $\mathrm{NaCl}$ is also observed since the slope of the $\Delta T$ evolution is superior from both host glasses. Besides $\Delta T$, two other parameters based on the characteristic temperatures are regularly explored in order to characterize the glasses. The first one is the so-called Hruby criterion $H_{r}=\left(T_{x}-T_{g}\right) /\left(T_{m}-T_{x}\right)$, which is

Table 1

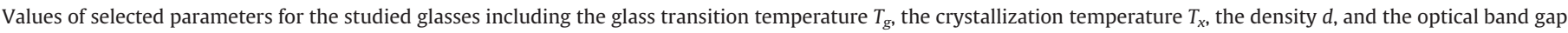
$E_{g}$. Glass-forming and thermal stability criteria are also given: $\Delta T=T_{x}-T_{g}$ and a criterion for glass ability against crystallization $H^{\prime}=\Delta T / T_{g}$.

\begin{tabular}{|c|c|c|c|c|c|c|}
\hline Sample composition & $T_{g}\left( \pm 2{ }^{\circ} \mathrm{C}\right)$ & $T_{x}\left( \pm 2^{\circ} \mathrm{C}\right)$ & $\Delta T\left( \pm 4^{\circ} \mathrm{C}\right)$ & $H^{\prime}( \pm 0.008)$ & $d\left( \pm 0.01 \mathrm{~g} \mathrm{~cm}^{-3}\right)$ & $E_{g}( \pm 0.02 \mathrm{eV})$ \\
\hline $80 \mathrm{GeS}_{2}-20 \mathrm{Ga}_{2} \mathrm{~S}_{3}$ & 442 & 520 & 78 & 0.109 & 2.93 & 2.64 \\
\hline$\left(80 \mathrm{GeS}_{2}-20 \mathrm{Ga}_{2} \mathrm{~S}_{3}\right)_{90}(\mathrm{LiI})_{10}$ & 406 & 532 & 126 & 0.186 & 2.99 & 1 \\
\hline$\left(80 \mathrm{GeS}_{2}-20 \mathrm{Ga}_{2} \mathrm{~S}_{3}\right)_{95}(\mathrm{NaCl})_{5}$ & 420 & 530 & 110 & 0.159 & 2.90 & 2.73 \\
\hline$\left(80 \mathrm{GeS}_{2}-20 \mathrm{Ga}_{2} \mathrm{~S}_{3}\right)_{90}(\mathrm{NaCl})_{10}$ & 396 & 535 & 139 & 0.208 & 2.87 & 2.81 \\
\hline$\left(80 \mathrm{GeS}_{2}-20 \mathrm{Ga}_{2} \mathrm{~S}_{3}\right)_{85}(\mathrm{NaCl})_{15}$ & 370 & 521 & 151 & 0.235 & 2.85 & 2.83 \\
\hline$\left(80 \mathrm{GeS}_{2}-20 \mathrm{Ga}_{2} \mathrm{~S}_{3}\right)_{95}(\mathrm{NaI})_{5}$ & 418 & 536 & 118 & 0.171 & 2.96 & 2.63 \\
\hline$\left(80 \mathrm{GeS}_{2}-20 \mathrm{Ga}_{2} \mathrm{~S}_{3}\right)_{90}(\mathrm{NaI})_{10}$ & 390 & 541 & 151 & 0.228 & 2.99 & 2.66 \\
\hline$\left(80 \mathrm{GeS}_{2}-20 \mathrm{Ga}_{2} \mathrm{~S}_{3}\right)_{85}(\mathrm{NaI})_{15}$ & 364 & 531 & 177 & 0.278 & 3.02 & 2.69 \\
\hline $72 \mathrm{GeS}_{2}-28 \mathrm{Ga}_{2} \mathrm{~S}_{3}$ & 428 & 485 & 57 & 0.081 & 3.00 & 2.58 \\
\hline$\left(72 \mathrm{GeS}_{2}-28 \mathrm{Ga}_{2} \mathrm{~S}_{3}\right)_{90}(\mathrm{LiI})_{10}$ & 382 & 498 & 116 & 0.177 & 3.04 & 1 \\
\hline$\left(72 \mathrm{GeS}_{2}-28 \mathrm{Ga}_{2} \mathrm{~S}_{3}\right)_{95}(\mathrm{NaCl})_{5}$ & 410 & 490 & 80 & 0.117 & 2.96 & 2.66 \\
\hline$\left(72 \mathrm{GeS}_{2}-28 \mathrm{Ga}_{2} \mathrm{~S}_{3}\right)_{90}(\mathrm{NaCl})_{10}$ & 394 & 503 & 109 & 0.163 & 2.92 & 2.74 \\
\hline$\left(72 \mathrm{GeS}_{2}-28 \mathrm{Ga}_{2} \mathrm{~S}_{3}\right)_{85}(\mathrm{NaCl})_{15}$ & 383 & 519 & 136 & 0.207 & 2.89 & 2.85 \\
\hline$\left(72 \mathrm{GeS}_{2}-28 \mathrm{Ga}_{2} \mathrm{~S}_{3}\right)_{95}(\mathrm{NaI})_{5}$ & 413 & 500 & 87 & 0.126 & 3.01 & 2.63 \\
\hline$\left(72 \mathrm{GeS}_{2}-28 \mathrm{Ga}_{2} \mathrm{~S}_{3}\right)_{90}(\mathrm{NaI})_{10}$ & 401 & 530 & 129 & 0.191 & 3.03 & 2.68 \\
\hline$\left(72 \mathrm{GeS}_{2}-28 \mathrm{Ga}_{2} \mathrm{~S}_{3}\right)_{85}(\mathrm{NaI})_{15}$ & 382 & I & 1 & 1 & 3.05 & 2.70 \\
\hline
\end{tabular}



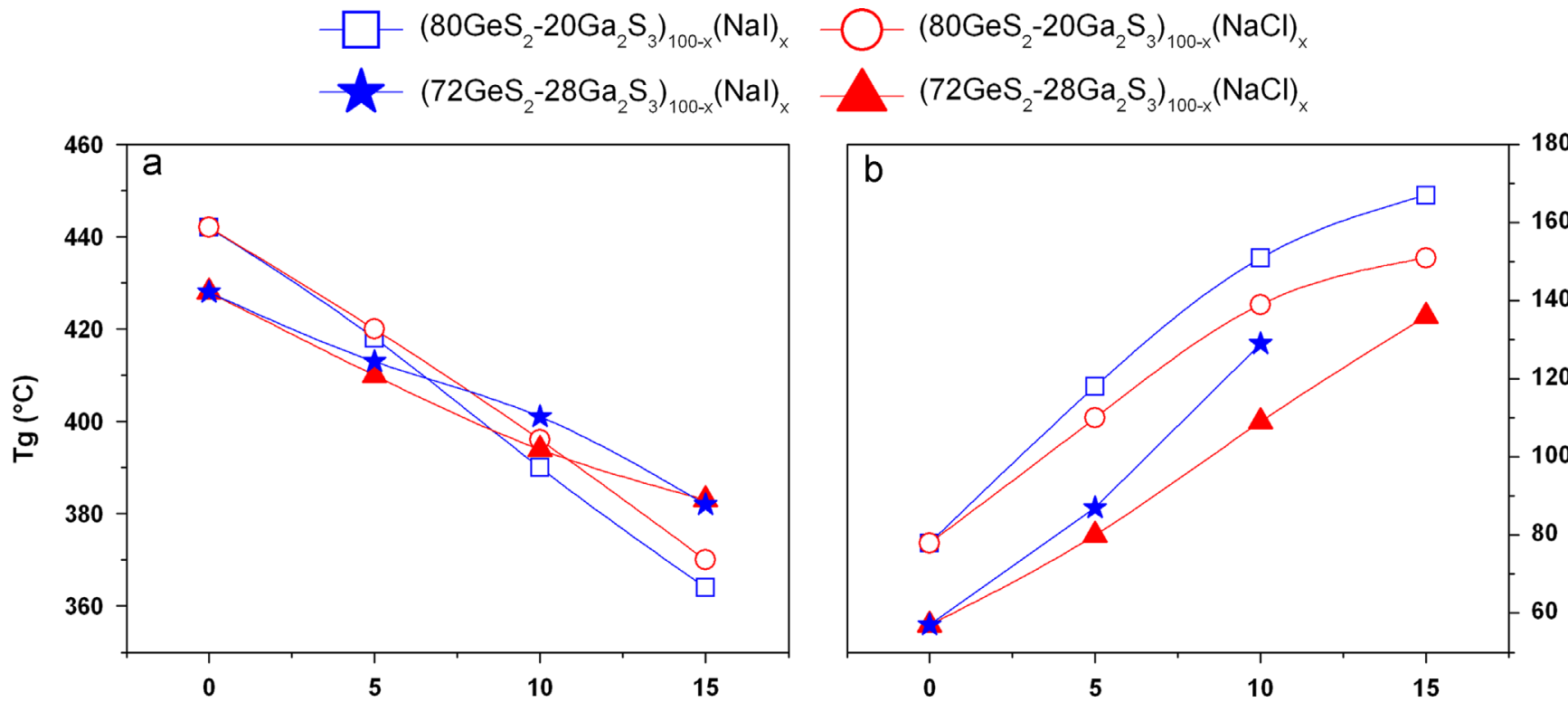

180

160

140

120
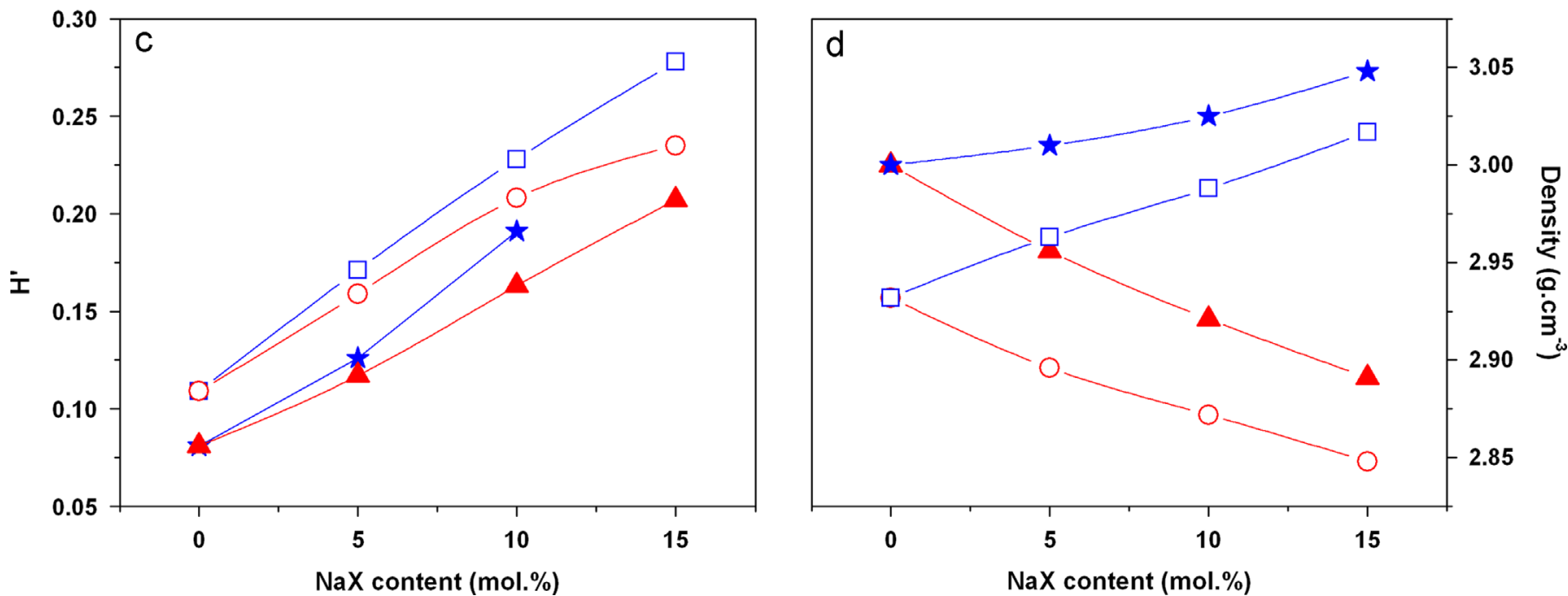

Fig. 1. Evolution of thermal and density parameters as a function of the $\mathrm{Na} X$ content $x, 0 \leq x \leq 15$, with $X=\mathrm{Cl}$ or I: (a) the glass transition temperature $T_{\mathrm{g}}$, (b) the difference between $T_{g}$ and $T_{x}, \Delta T$, corresponding to the crystallization temperature, (c) the criterion $H^{\prime}$ relative to the stability of the glass against crystallization, and (d) the density.

used to evaluate the glass forming ability [22]. In case of high melting temperatures $T_{m}$, an alternative criterion $H^{\prime}$ is also used to estimate the glass forming ability against crystallization, $H^{\prime}=\Delta T / T_{g}$ [23]. This last parameter, plotted in Fig. 1c, exhibits similar trend than the $\Delta T$ parameter following the $\mathrm{NaX}$ content. Finally, $H^{\prime}$ and $\Delta T$ values increase following the $\mathrm{NaX}$ additions meaning that both thermal stability and glass forming ability are better for the richest $\mathrm{NaX}$-bearing compositions. This can be attributed to the halogenide anions $\mathrm{X}^{-}$that are well known to progressively break the Ge-S or $\mathrm{Ga}-\mathrm{S}$ bonds and partially form the complex anion $\mathrm{Ga}(\mathrm{Ge}) \mathrm{S}_{3 / 2}$ $\mathrm{X}^{-}$tetrahedral. This structural unit is then assumed to favor the glass formation [24]. The results also point out the more positive effect of the iodide salt comparatively to the chloride one.

The evolution of the density exhibited in Fig. 1d is different for sodium chloride- and sodium iodide-bearing glasses. In $\mathrm{NaCl}-$ based glasses, the density monotonously decreases following the $\mathrm{NaCl}$ content whereas in NaI-based glasses it monotonously increases. These contrary behaviors can be ascribed to the relative mean atomic weights of $\mathrm{NaCl}$ and $\mathrm{NaI}$ compared to the host glass ones. For $\mathrm{NaCl}$ it is $29.2 \mathrm{~g}$ and for $\mathrm{NaI}$ it is $75.0 \mathrm{~g}$, whereas for $80 \mathrm{GeS}_{2}-20 \mathrm{Ga}_{2} \mathrm{~S}_{3}$ and $72 \mathrm{GeS}_{2}-28 \mathrm{Ga}_{2} \mathrm{~S}_{3}$, the relative mean atomic weights are $45.8 \mathrm{~g}$ and $45.9 \mathrm{~g}$, respectively.

\subsection{Optical properties}

The addition of $\mathrm{NaX}$ in $\mathrm{GeS}_{2}-\mathrm{Ga}_{2} \mathrm{~S}_{3}$ based glasses is characterized by a blue-shift of the visible transmission as shown in Fig. 2a for the selected compositions $\left(72 \mathrm{GeS}_{2}-28 \mathrm{Ga}_{2} \mathrm{~S}_{3}\right)_{100-x}(\mathrm{NaX})_{x}$, with $X=\mathrm{I}$ or $\mathrm{Cl}$ and $5 \leq x \leq 15$. A photograph of two different glasses after polishing are also given; the parallelepiped and tablet samples correspond to the composition $\left(72 \mathrm{GeS}_{2}-28 \mathrm{Ga}_{2} \mathrm{~S}_{3}\right)_{90}(\mathrm{NaI})_{10}$ and $\left(72 \mathrm{GeS}_{2}-28 \mathrm{Ga}_{2} \mathrm{~S}_{3}\right)_{90}(\mathrm{NaCl})_{10}$, respectively. In Fig. $2 \mathrm{~b}$, the evolution of the optical band gap $E_{g}$ for the four investigated series are plotted. As first observation, we can notice that $E_{g}$ grows up whatever the sodium halogenide added in the host glass. The second observation is the lower increase of $E_{g}$ when the sodium iodide is added instead of the sodium chloride. From the $\left(80 \mathrm{GeS}_{2}-\right.$ $20 \mathrm{Ga}_{2} \mathrm{~S}_{3}$ ) host glass $E_{g}$ evolves from $0.05 \mathrm{eV}$ and $0.19 \mathrm{eV}$ by adding up to $15 \mathrm{~mol} \%$ of $\mathrm{NaI}$ and $\mathrm{NaCl}$, respectively, and from the $\left(72 \mathrm{GeS}_{2}-\right.$ $28 \mathrm{Ga}_{2} \mathrm{~S}_{3}$ ) host glass $E_{\mathrm{g}}$ progresses from $0.12 \mathrm{eV}$ and $0.27 \mathrm{eV}$ in similar conditions. These general behaviors are often observed when halogen is introduced in the composition of a chalcogenide glasses [20]. As already mentioned, the introduction of chlorine or iodine is supposed to progressively break the $\mathrm{Ge}-\mathrm{S}$ or $\mathrm{Ga}-\mathrm{S}$ to form $\mathrm{Ga}(\mathrm{Ge}) \mathrm{S}_{4-y} \mathrm{X}_{y}$ tetrahedral units. In other words, the average number 
a

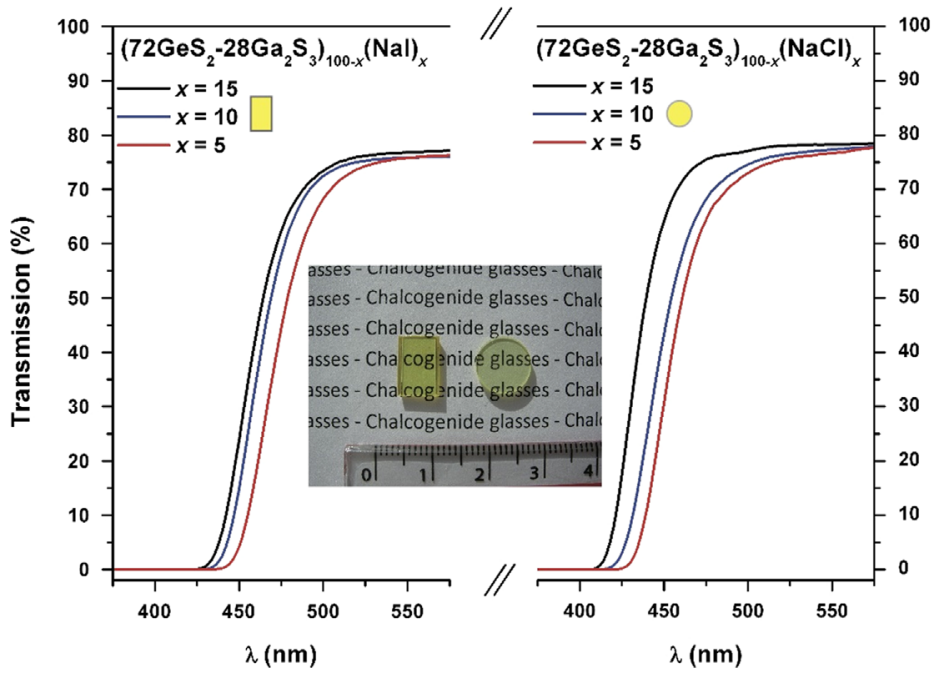

b

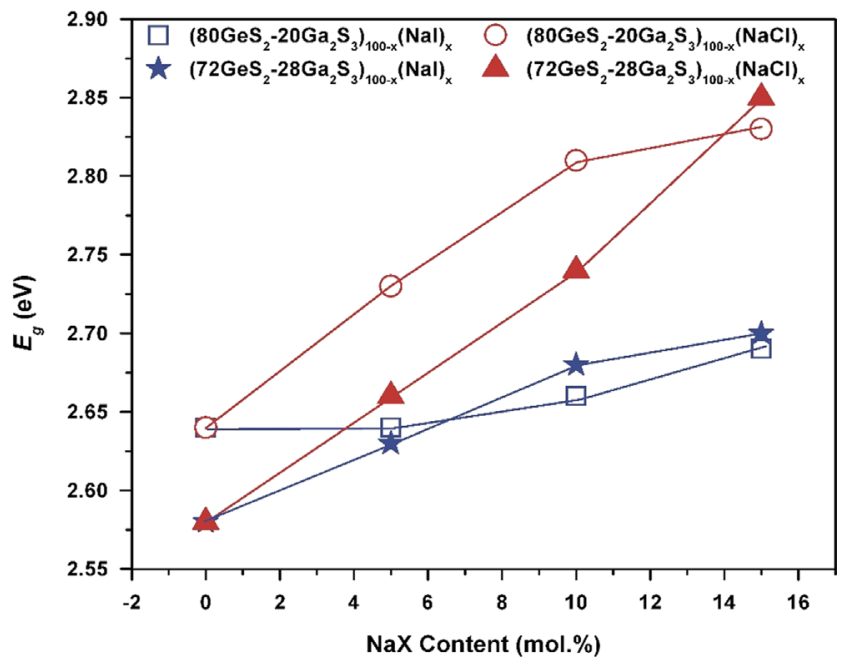

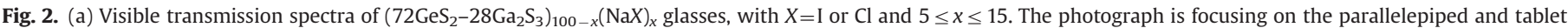

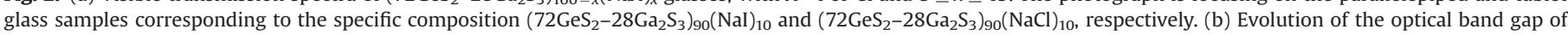
the four series $\left(72 \mathrm{GeS}_{2}-28 \mathrm{Ga}_{2} \mathrm{~S}_{3}\right)_{100-x}(\mathrm{NaX})_{x}$ and $\left(80 \mathrm{GeS}_{2}-20 \mathrm{Ga}_{2} \mathrm{~S}_{3}\right)_{100-x}(\mathrm{NaX})_{x}$ glasses, with $X=\mathrm{I}$ or $\mathrm{Cl}$ and $5 \leq x \leq 15$.

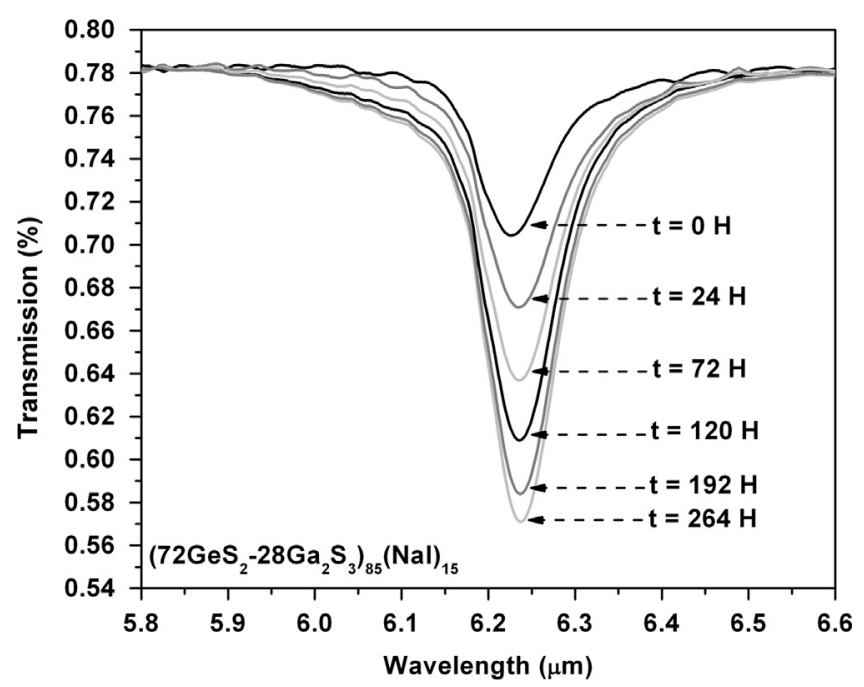

Fig. 3. Evolution of the $\mathrm{H}_{2} \mathrm{O}$ absorption band located at $6.23 \mu \mathrm{m}$ after different time $(t=0 \mathrm{~h}, 24 \mathrm{~h}, 72 \mathrm{~h}, 120 \mathrm{~h}, 192 \mathrm{~h}$, and $264 \mathrm{~h})$ for the specific composition $\left(72 \mathrm{GeS}_{2}-\right.$ $\left.28 \mathrm{Ga}_{2} \mathrm{~S}_{3}\right)_{85}(\mathrm{NaI})_{15}$.

of $\mathrm{Ge}-\mathrm{S}$ and $\mathrm{Ga}-\mathrm{S}$ bonds is lower and the $\mathrm{Ge}-\mathrm{Cl}$ or $\mathrm{Ge}-\mathrm{I}$ ones is increased. In Pauling scale, the electronegativity of $\mathrm{Ga}, \mathrm{Ge}, \mathrm{S}, \mathrm{Cl}$, and I are $1.81,2.01,2.58,3.16$, and 2.66 , respectively. So, the electronegativity difference of the Ga-S is 0.77 and Ge-S is 0.57 whereas for $\mathrm{Ga}-\mathrm{Cl}$ it is 1.35 , Ge-Cl it is 1.15 , Ga-I it is 0.85 , and $\mathrm{Ge}-\mathrm{I}$ it is 0.65 . Consequently, the average electronegativity of the material grows up if $\mathrm{Cl}^{-}$or $\mathrm{I}^{-}$anions are added in the composition of the glasses leading to a low wavelength-shift of $E_{g}$ [25]. This explanation is supported by the lower white-shift of the NaI based samples comparatively to the $\mathrm{NaCl}$ ones.

\subsection{Resistance to humidity}

Alkali halide compounds are well known to be poorly resistant towards humidity. To evaluate the effect of the progressive addition of $\mathrm{NaX}$ in the host glasses it is possible to observe the evolution of the water absorption band located around $6.23 \mu \mathrm{m}$ as the function of the time. The first infrared transmission measurement was implemented just after polishing in ethanol.
Fig. 3 emphasizes its increasing evolution for the particular glass sample $\left(72 \mathrm{GeS}_{2}-28 \mathrm{Ga}_{2} \mathrm{~S}_{3}\right)_{85}(\mathrm{NaI})_{15}$ after $0 \mathrm{~h}, 24 \mathrm{~h}, 72 \mathrm{~h}, 120 \mathrm{~h}$, $192 \mathrm{~h}$, and $264 \mathrm{~h}$ without any additional polishing. Analogous study was carried out for other glasses $\left(\left(72 \mathrm{GeS}_{2}-28 \mathrm{Ga}_{2} \mathrm{~S}_{3}\right)_{100-x}\right.$ $(\mathrm{NaX})_{x}$ glasses, with $X=\mathrm{I}$ or $\mathrm{Cl}$ and $\left.5 \leq x \leq 15\right)$ and Fig. 4 exhibits the evolution of their $\mathrm{H}_{2} \mathrm{O}$ band intensity. It is clearly observed that the increasing intensity is more pronounced in the case of $\mathrm{NaI}$ based glasses. No surprisingly, as observed in Fig. 4, this growing evolution is more important for the high content in $\mathrm{NaX}$. One can also observe that the intensity is growing up for all samples and that this increase is more important in the first hours. This is consistent with a corrosion of the samples majority, indeed exclusively, at their surfaces, already observed for other chalcogenide glasses in more drastic conditions [26]. The corrosion mechanism is probably due to the ion exchange between halide ions and hydroxyl ions $\mathrm{OH}^{-}$that occurs at the glass surface. Since iodine is less electronegative than chlorine the substitution between $\mathrm{I}^{-}$and $\mathrm{OH}^{-}$anions is easier than between $\mathrm{Cl}^{-}$and $\mathrm{OH}^{-}$anions at the glass surface, meaning that the stability against humidity is less in case of NaI-bearing glasses compared to $\mathrm{NaCl}-$ bearing glasses.

\subsection{Electrical conductivity}

Complex impedance plots of the $\left(80 \mathrm{GeS}_{2}-20 \mathrm{Ga}_{2} \mathrm{~S}_{3}\right)_{90}(\mathrm{NaCl})_{10}$ glasses at different temperatures is shown in Fig. 5a as typical example. In Fig. 5b, other plots recorded at $100{ }^{\circ} \mathrm{C}$ are shown. They correspond to glass samples containing $10 \mathrm{~mol} \%$ of $\mathrm{NaCl}$ or LiI in $80 \mathrm{GeS}_{2}-20 \mathrm{Ga}_{2} \mathrm{~S}_{3}$ or $72 \mathrm{GeS}_{2}-28 \mathrm{Ga}_{2} \mathrm{~S}_{3}$. Fig. 5a exhibits an expected trend as a function of the temperature. Whatever the temperature, we can observe the typical spectrum of an ionic conductor, which consisted in a high-frequency semi-circle and a low-frequency tail. This low-frequency polarization characterizes the difficulties of the charge transfer at the Au/Glass interface of the electrochemical cell. This phenomenon seems to be more pronounced for Li-based glasses compared to the Na-based ones.

The linear temperature dependence on the conductivity $\sigma$ for selected glasses is exhibited in Fig. 6. All data obey the Arrhenius law

$\sigma=\frac{\sigma_{0}}{T} \exp \left(\frac{-E_{\sigma}}{k T}\right)$ 


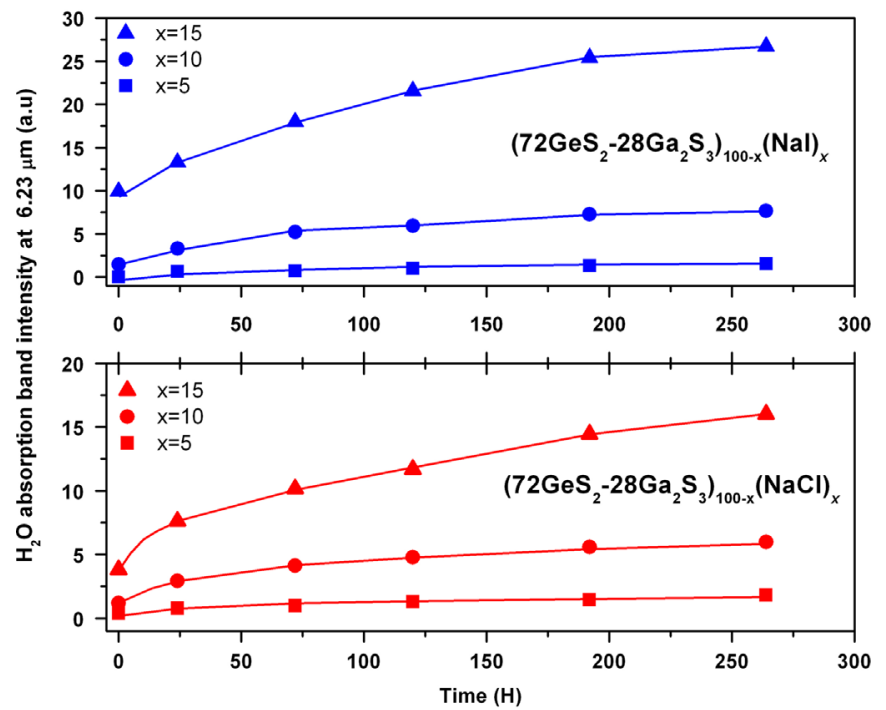

Fig. 4. Evolution of the $\mathrm{H}_{2} \mathrm{O}$ absorption band intensity located at $6.23 \mu \mathrm{m}$ after different time $(t=0 \mathrm{~h}, 24 \mathrm{~h}, 72 \mathrm{~h}, 120 \mathrm{~h}, 192 \mathrm{~h}, 264 \mathrm{~h})$ for $\left(72 \mathrm{GeS}_{2}-28 \mathrm{Ga}_{2} \mathrm{~S}_{3}\right)_{100-x}(-$ $\mathrm{NaX})_{x}$ glasses, with $X=\mathrm{I}$ or $\mathrm{Cl}$ and $5 \leq x \leq 15$.

where $\sigma_{0}$ is the pre-exponential factor, $E_{\sigma}$ is the activation energy, $k$ is the Boltzmann constant and $T$ is the temperature. $E_{\sigma}, \sigma_{0}$, and the room-temperature conductivity $\sigma_{298}$ were obtained by fitting the conductivity to the Arrhenius equation and are listed in Table 2.

The investigated glasses over the limited composition range show a few changes in the room-temperature conductivity $\sigma_{298}$. The $\sigma_{298}$ increases with mobile cation concentration from $3.9 \times 10^{-8} \mathrm{~S} \mathrm{~cm}^{-1}$ (Nal-doped glass, 2.9 at\% $\mathrm{Na}$ ) to $1.8 \times 10^{-6} \mathrm{~S} \mathrm{~cm}^{-1}\left(\mathrm{Li}_{2} \mathrm{~S}-\mathrm{Ga}_{2} \mathrm{~S}_{3}-\mathrm{GeS}_{2}\right.$, 5.7 at\% Li) while the mobile cation content is doubled (Fig. 7). The conductivity activation energy varies weakly between 0.53 and $0.58 \mathrm{eV}$. Our results agree reasonably well with the published conductivity data on similar glassy systems [16,24,27]

As expected, $\mathrm{Li}^{+}$ion conducting glasses show a better ionic transport at comparable cation concentration $x$ of $\approx 3$ at\%. Nevertheless, at higher $x$ both $\mathrm{Li}^{+}$and $\mathrm{Na}^{+}$glassy systems seem to have similar conductivity parameters. We did not observe either a pronounced positive effect of large polarizable iodine anion on the ionic transport properties in the $M X-\mathrm{Ga}_{2} \mathrm{~S}_{3}-\mathrm{GeS}_{2}$ glasses over the investigated composition range in marked contrast to other chalcohalide glassy systems [28-30]. In addition, the lithium sulfide vitreous alloy also shows a higher conductivity at $298 \mathrm{~K}$ compared to LiCl-, Lil-, NaCl- and NaI-containing glasses (Fig. 7). The influence of the glass matrix composition, in other words, the $\mathrm{GeS}_{2} / \mathrm{Ga}_{2} \mathrm{~S}_{3}$ ratio is found to be weakly significant compared to the effect of the cation. Indeed, for the three investigated salt $M X(\mathrm{NaI}$, $\mathrm{NaCl}$, and LiI) one can see a higher conductivity for the 80/20 ratio comparatively to the $72 / 28$ ratio. This observation is consistent with a future study in which this trend is confirmed by investigating other $\mathrm{GeS}_{2} / \mathrm{Ga}_{2} \mathrm{~S}_{3}$ ratios [31].

In order to solve the observed puzzle, further conductivity measurements over extended composition range are needed and especially the advanced structural studies. However, in current situation, we can ask whether the relative insensitivity of the glass ionic conductivity to the chemical form of ionic dopant (MI, $\mathrm{MCl}$ or $\mathrm{M}_{2} \mathrm{~S}$ ) is related to the glass packing density $\rho$ [32,33]. This empiric structural parameter is a ratio between the average atomic volume of the glass constituents $V_{a}^{0}$, calculated using glass stoichiometry and ionic radii, and the average glass atomic volume $V_{a}$ derived from glass stoichiometry and density

$\rho=\frac{V_{a}^{0}}{V_{a}}$

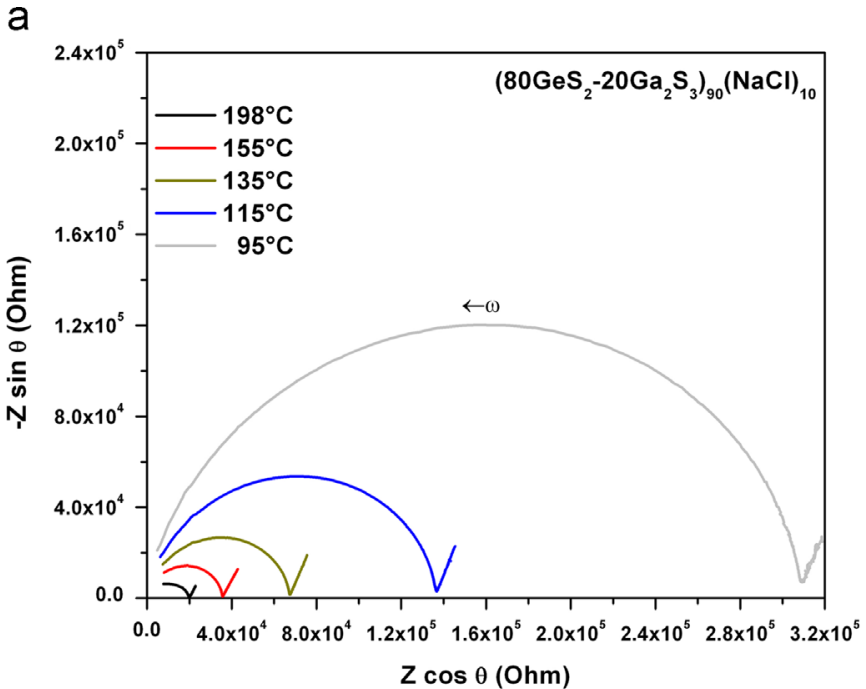

b

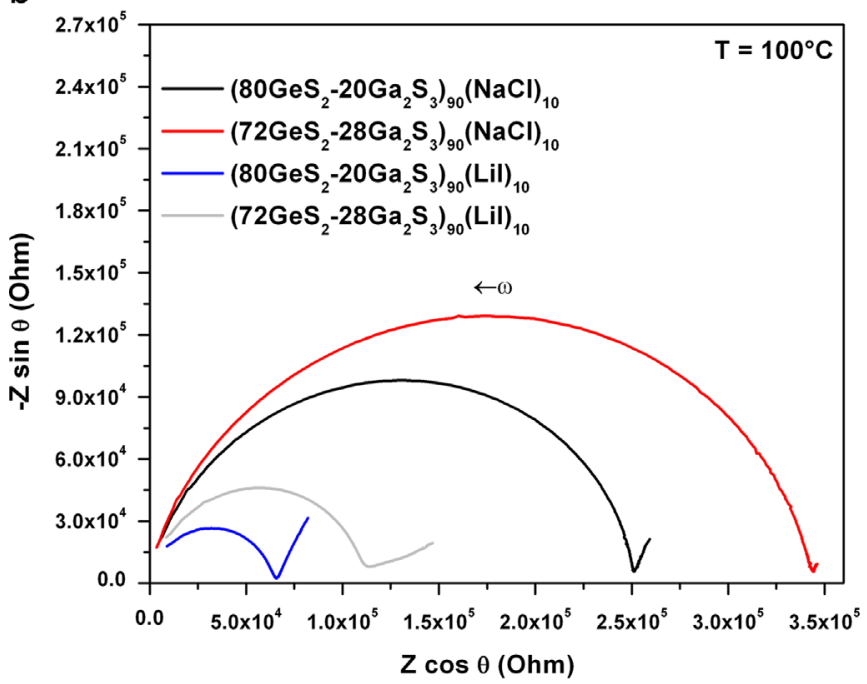

Fig. 5. (a) Evolution of the Cole-Cole diagrams of the specific glass composition $\left(80 \mathrm{GeS}_{2}-20 \mathrm{Ga}_{2} \mathrm{~S}_{3}\right)_{90}(\mathrm{NaCl})_{10}$ for different temperatures $T$. (b) Isothermal $\left(100{ }^{\circ} \mathrm{C}\right)$ Cole-Cole diagrams for different glass compositions.

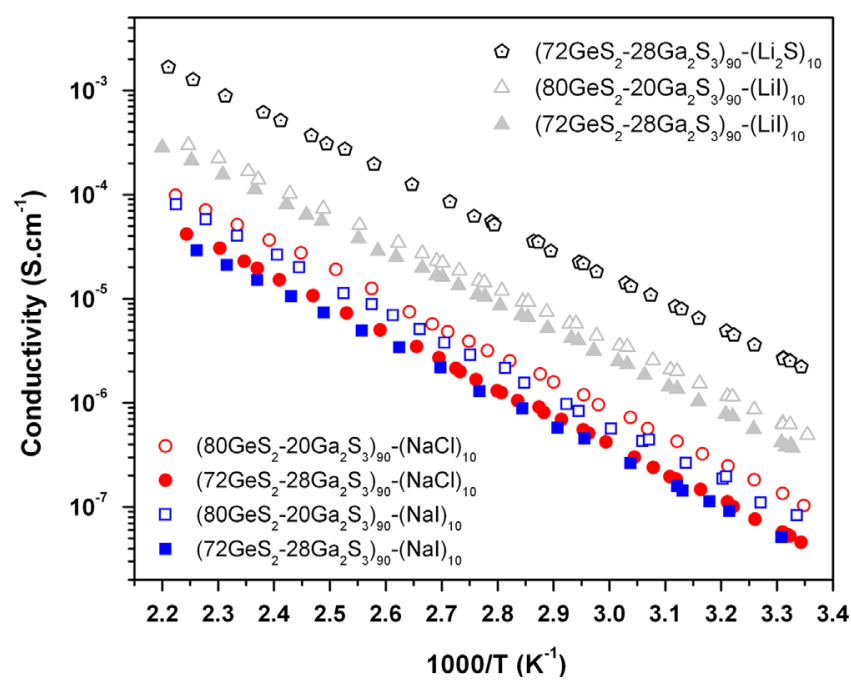

Fig. 6. Temperature dependence of the total electrical conductivity $\sigma$ for glass compositions containing $10 \mathrm{~mol} \%$ of $\mathrm{NaCl}$, NaI, Lil, and $\mathrm{Li}_{2} \mathrm{~S}$ in $80 \mathrm{GeS}_{2}-20 \mathrm{Ga}_{2} \mathrm{~S}_{3}$ (open symbols) or $72 \mathrm{GeS}_{2}-28 \mathrm{Ga}_{2} \mathrm{~S}_{3}$ (full symbols). 
Table 2

Conductivity parameters for selected glass compositions: the room-temperature conductivity $\sigma_{298}$, the activation energy $E_{\sigma}$ and the pre-exponential factor $\sigma_{0}$. Uncertainties on the last digit are given in parentheses.

\begin{tabular}{llll}
\hline Composition & $\log \sigma_{298}\left(\mathrm{~S} \mathrm{~cm}^{-1}\right)$ & $E_{\sigma}(\mathrm{eV})$ & $\log \sigma_{0}\left(\mathrm{~S} \mathrm{~cm}^{-1} \mathrm{~K}\right)$ \\
\hline$\left(80 \mathrm{GeS}_{2}-20 \mathrm{Ga}_{2} \mathrm{~S}_{3}\right)_{90}-(\mathrm{LiI})_{10}$ & $-6.34(5)$ & $0.535(4)$ & $5.18(5)$ \\
$\left(80 \mathrm{GeS}_{2}-20 \mathrm{Ga}_{2} \mathrm{~S}_{3}\right)_{90}-(\mathrm{NaCl})_{10}$ & $-6.92(5)$ & $0.544(4)$ & $4.75(5)$ \\
$\left(80 \mathrm{GeS}_{2}-20 \mathrm{Ga}_{2} \mathrm{~S}_{3}\right)_{90}-(\mathrm{NaI})_{10}$ & $-7.24(3)$ & $0.582(3)$ & $5.08(3)$ \\
$\left(72 \mathrm{GeS}_{2}-28 \mathrm{Ga}_{2} \mathrm{~S}_{3}\right)_{90}-\left(\mathrm{Li}_{2} \mathrm{~S}\right)_{10}$ & $-5.74(3)$ & $0.545(3)$ & $5.95(3)$ \\
$\left(72 \mathrm{GeS}_{2}-28 \mathrm{Ga}_{2} \mathrm{~S}_{3}\right)_{90}-(\mathrm{LiI})_{10}$ & $-6.44(2)$ & $0.529(2)$ & $4.97(2)$ \\
$\left(72 \mathrm{GeS}_{2}-28 \mathrm{Ga}_{2} \mathrm{~S}_{3}\right)_{90}-(\mathrm{NaCl})_{10}$ & $-7.34(4)$ & $0.561(4)$ & $4.62(4)$ \\
$\left(72 \mathrm{GeS}_{2}-28 \mathrm{Ga}_{2} \mathrm{~S}_{3}\right)_{90}-(\mathrm{NaI})_{10}$ & $-7.41(3)$ & $0.554(2)$ & $4.43(5)$ \\
\hline
\end{tabular}

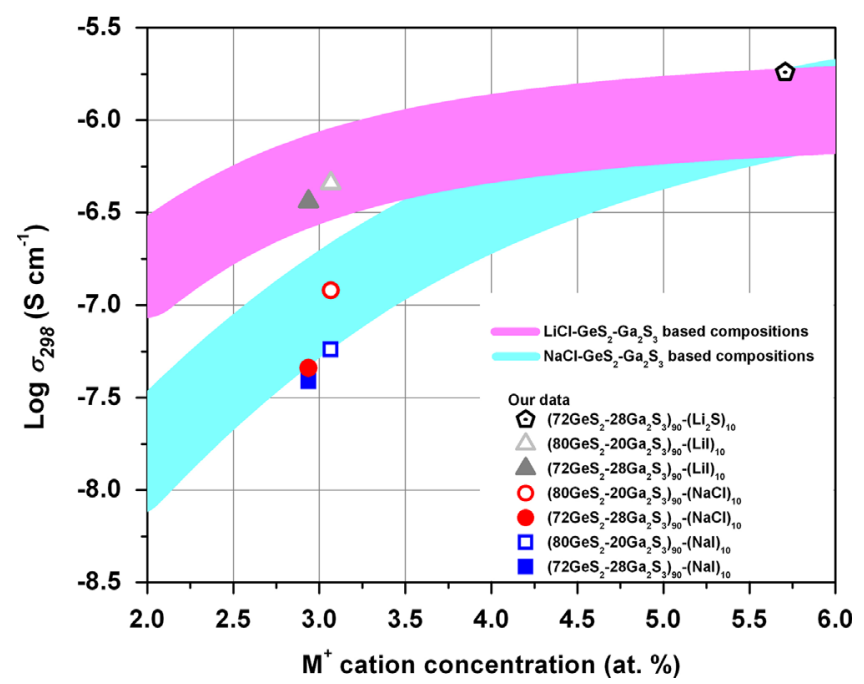

Fig. 7. Room-temperature conductivity $\sigma_{298}$ of investigated glasses: (i) $\left(80 \mathrm{GeS}_{2}-\right.$ $\left.20 \mathrm{Ga}_{2} \mathrm{~S}_{3}\right)_{90}(M X)_{10}$ (open symbols) with $M X=\mathrm{NaI}$ (blue) or $\mathrm{NaCl}$ (red) or Lil (light gray), (ii) $\left(72 \mathrm{GeS}_{2}-28 \mathrm{Ga}_{2} \mathrm{~S}_{3}\right)_{90}(M X)_{10}$ (full symbols) with $M X=\mathrm{NaI}$ (blue) or $\mathrm{NaCl}$ (red) or LiI (light gray), and (iii) $\left(72 \mathrm{GeS}_{2}-28 \mathrm{Ga}_{2} \mathrm{~S}_{3}\right)_{90}\left(\mathrm{Li}_{2} \mathrm{~S}\right)_{10}$ (black symbol). The reported data corresponding to mean conductivity at $298 \mathrm{~K}[23,26]$ for the $\mathrm{NaCl}-$ $\mathrm{Ga}_{2} \mathrm{~S}_{3}-\mathrm{GeS}_{2}$ (blue line) and $\mathrm{LiCl}-\mathrm{Ga}_{2} \mathrm{~S}_{3}-\mathrm{GeS}_{2}$ (light brown line) glassy systems are also shown for comparison. (For interpretation of the references to color in this figure legend, the reader is referred to the web version of this article.)

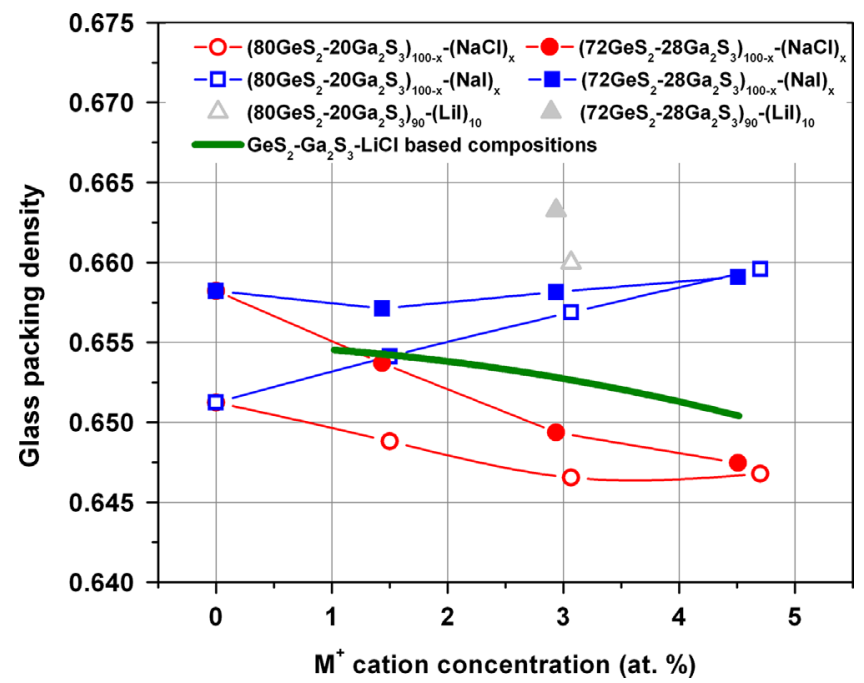

Fig. 8. The derived glass packing density $\rho$ of the investigated glasses as a function of the $\mathrm{M}^{+}$cationic concentration: (i) $\left(80 \mathrm{GeS}_{2}-20 \mathrm{Ga}_{2} \mathrm{~S}_{3}\right)_{100-x}(M X)_{x}$ (open symbols)

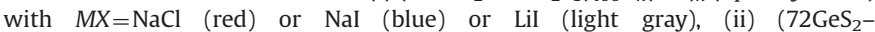
$\left.28 \mathrm{Ga}_{2} \mathrm{~S}_{3}\right)_{90}-(M X)_{10}$ (full symbols) with $M X=\mathrm{NaCl}$ (red) or NaI (blue) or Lil (light gray). The reported glass packing density $\rho$ [26] for the $\mathrm{LiCl}-\mathrm{Ga}_{2} \mathrm{~S}_{3}-\mathrm{GeS}_{2}$ (green line) is also shown for comparison. (For interpretation of the references to color in this figure legend, the reader is referred to the web version of this article.)
$V_{a}^{0}=\sum_{i} c_{i} \frac{4 \pi}{3} r_{i}^{3}$

$V_{a}=\frac{\sum_{i} c_{i} M_{i}}{d N_{A}}$

where $c_{i}$ is the atomic fraction of the element $i, M_{i}$ and $r_{i}$ are the respective atomic mass and Shannon ionic radius, $N_{A}$ the Avogadro constant. The high glass packing density $\rho \rightarrow 1$ means the absence of free space for atomic motion similar to negative effect of highpressure on the ionic transport [34,35]. The opposite case, low $\rho$, is favorable for fast ionic mobility. Large cationic ( $\mathrm{Pb}, \mathrm{Hg}$, etc.) and anionic (I, Te, etc.) species are suggested to increase the ionic conductivity via the increasing available free volume [36,37]. The calculated glass packing densities for the investigated glasses are shown in Fig. 8. Surprisingly, neither lithium nor sodium iodides do significantly increase the available free volume $(1-\rho)$ in the glass, thus explaining the relative insensitivity of the chemical doping form ( $\mathrm{MCl}$ vs. MI) on the $\mathrm{Li}^{+}$or $\mathrm{Na}^{+}$ionic conductivity in the $M X-\mathrm{Ga}_{2} \mathrm{~S}_{3}-\mathrm{GeS}_{2}$ glasses over limited composition range.

\section{Conclusion}

Glass samples in the $\mathrm{NaX}-\mathrm{GeS}_{2}-\mathrm{Ga}_{3} \mathrm{~S}_{2}$ system, with $X=\mathrm{Cl}$ or I have been prepared. Whatever is the halide, the increment of the $\mathrm{NaX}$ molar percentage leads to a similar trend for thermal characteristics. A decrease of the glass transition temperature and an increase of both glass-forming ability and thermal stability have been emphasized. At contrary, density shows reverse behaviors, which has been attributed to the mass of the sodium halide. The temperature dependence of the conductivity, which has to be considered as ionic, follows an Arrhenius type equation for all investigated glasses. The relative low effect of the chemical doping form ( $\mathrm{MCl}$ vs. MI) on the ionic conductivity coming from the mobility of the $\mathrm{Na}^{+}$or $\mathrm{Li}^{+}$cations has been discussed following a hypothesis based on the glass packing density.

\section{Acknowledgments}

This work is funded by the "Agence Nationale de la Recherche" through the ASTRID program and the "Direction Générale de l'Armement".

\section{References}

[1] H. Guo, Y. Zhai, H. Tao, G. Dong, X. Zhao, Mater. Sci. Eng. B Solid 138 (2007) $235-240$.

[2] A. Tverjanovich, Y.S. Tveryanovich, S. Loheider, J. Non-Cryst. Solids 208 (1996) 49-55.

[3] P. Masselin, D. Le Coq, A. Cuisset, E. Bychkov, Opt. Mater. Exp. 2 (12) (2012) $1768-1775$.

[4] K. Wei, D.P. Machewirth, J. Wenzel, E. Snitzer, G.H. Sigel, J. Non-Cryst. Solids 182 (1995) 257-261.

[5] A. Tverjanovich, Ya.G. Grigoriev, S.V. Degtyarev, A.V. Kurochkin, A.A. Man'shina, Yu.S. Tver'yanovich, J. Non-Cryst. Solids 286 (2001) 89-92.

[6] T.Yu. Ivanova, A.A. Man'shina, A.V. Kurochkin, Yu.S. Tver'yanovich, V.B. Smirnov, J. Non-Cryst. Solids 298 (2002) 7-14.

[7] B. Fan, C. Point, J.-L. Adam, X. Zhang, X. Fan, H. Ma, J. Appl. Phys. 110 (11) (2011) 113107-113108.

[8] H. Ma, L. Calvez, B. Bureau, M.L. Floch, X. Zhang, J. Lucas, J. Phys. Chem. Solids 68 (2007) 968-971.

[9] L. Calvez, H. Ma, J. Lucas, P. Glouannec, X. Zhang, J. Non-Cryst. Solids 353 (2007) 4702-4706.

[10] C. Lin, L. Calvez, H. Tao, M. Allix, A. Moréac, X.H. Zhang, X. Zhao, J. Solids State Chem. 184 (3) (2011) 584-588.

[11] Y. Ledemi, B. Bureau, L. Calvez, M. Le Floch, M. Rozé, C. Lin, X.H. Zhang, M. Allix, G. Matzen, Y. Messaddeq, J. Phys. Chem. B 113 (44) (2009) 14474-14580.

[12] W. Yao, S.W. Martin, Solid State Ion. 178 (2008) 1777-1784.

[13] M. Yamashita, H. Yamanaka, Solid State Ion. 158 (2003) 151-156.

[14] J. Saienga, S.W. Martin, J. Non-Cryst. Solids 354 (2008) 1475-1486. 
[15] B. Roling, A. Schirmeisen, H. Bracht, A. Taskiran, H. Fuchs, S. Murugavel, F. Natrup, Phys. Chem. Chem. Phys. 7 (2005) 1472-1475.

[16] C. Lin, L. Calvez, B. Bureau, T. Haizheng, M. Allix, Z. Hao, V. Seznec, X. Zhang, X. Zhao, Phys. Chem. Chem. Phys. 12 (2010) 3780-3787.

[17] S. Stehlik, V. Zima, T. Wagner, J. Ren, M. Frumar, Solid State Ion. 179 (2008) 1867-1875.

[18] J. Kolář, T. Wágner, V. Zima, Š. Stehlík, B. Frumarová, L. Beneš, M. Vlček, M. Frumar, S.O. Kasap, J. Non-Cryst. Solids 357 (11-13) (2011) 2223-2227.

[19] A. Hayashi, K. Noi, A. Sakuda, M. Tatsumisago, Nat. Commun. 3 (2012) 856.

[20] P. Masselin, D. Le Coq, L. Calvez, E. Petracovschi, E. Lépine, E. Bychkov, X.H. Zhang, Appl. Phys. A Mater. Sci. Process. 106 (3) (2012) 697-702.

[21] C. Lin, G.S. Qu, Z.B. Li, S.X. Dai, H.L. Ma, T.F. Xu, Q.H. Nie, X.H. Zhang, J. Am. Ceram. Soc. 96 (6) (2013) 1779-1782.

[22] A. Hruby, Czech. J. Phys. B 22 (1972) 1187-1193.

[23] J. Heo, J.K. Park, Y.S. Kim, J. Non-Cryst. Solids 175 (2-3) (1994) 204-210.

[24] Y.S. Tver'yanovich, V.V. Aleksandrov, I.V. Murin, E.G. Nedoshovenko, J. NonCryst. Solids 256-257 (1999) 237-241.

[25] M.P. Hehlen, B.L. Bennett, A. Castro, D.J. Williams, S.C. Tornga, R.E. Muenchausen, Opt. Mater. 32 (2010) 491-499.
[26] L. Calvez, P. Lucas, M. Rozé, H.L. Ma, J. Lucas, X.H. Zhang, Appl. Phys. A 89 (2007) 183-188.

[27] Z.U. Borisova, E.A. Bychkov, Yu.S. Tver'yanovich, Interaction of Metals with Chalcogenide Glasses, Leningrad State University, Leningrad, 1991.

[28] J.P. Malugani, G. Robert, Mater. Res. Bull. 14 (1979) 1075-1081.

[29] B. Carette, M. Maurin, M. Ribes, M. Duclot, Solid State Ion. 9-10 (1983 655-658.

[30] E. Bychkov, D.L. Price, C.J. Benmore, A.C. Hannon, Solid State Ion. 154-155 (2002) 349-359.

[31] A. Bréhault, S. Cozic, L. Calvez, X.H. Zhang, D. Le Coq, 2014, in preparation.

[32] U. Hoppe, J. Non-Cryst. Solids 248 (1999) 11-18.

33] A. Masuno, S. Kohara, A.C. Hannon, E. Bychkov, H. Inoue, Chem. Mater. 25 (2013) 3056-3061.

[34] S.W. Kurnick, J. Chem. Phys. 20 (1952) 218-228.

[35] H. Mehrer, A.W. Imre, E. Tanguep-Nijokep, J. Phys.: Conf. Ser. 106 (2008) 012001.

[36] Yu.G. Vlasov, E.A. Bychkov, B.L. Seleznev, Solid State Ion. 24 (1987) 179-187.

[37] R. Boidin, I. Alekseev, K. Michel, D. Le Coq, E. Bychkov, Solid State Ion. 262 (2014) 821-823. 